\title{
ASRO (Amphibious Spy Robot): Prototipe Robot Amfibi Pengintai Dengan First Person View Dan Sistem Navigasi Berbasis Sensor Kompas
}

\author{
R. Amirur Rajif ${ }^{1}$, Fatchul Arifin ${ }^{2}$ \\ 1,2Program Studi Teknik Elektronika Fakultas Teknik Universitas Negeri Yogyakarta \\ E-mail: r.a.rajif@gmail.com
}

\begin{abstract}
Robots have an important role in all aspects of life, including the military field. The purpose of making this final project are building hardware and software of robot and to know the performance of robots. The method used in making the final project consists of identifying and analyzing requirements, designing and manufacturing hardware and software, and testing. The result of the performance of ASRO is that, the buoyancy force of the robot is greater than the weight of the object, namely $\mathrm{Fa}=22,808 \mathrm{~N}$ and $\mathrm{W}=15,696 \mathrm{~N}$ or $\mathrm{Fa}>\mathrm{W}$ which makes the robot float while operate in the water field. The maximum range of control system robot is as far as 0-30 meters without obstacles and 0-15 meters with obstacles, while the monitoring system is as far as 0-75 meters without obstacles and 0-30 meters with obstacles. The Robot navigation system has a percentage of accuracy of reading $93.3 \%$ and the percentage response of the average robot when rotating $90^{\circ}$ is $100 \%$, rotating $180^{\circ}$ is $100 \%$, and rotating $270^{\circ}$ is $100 \%$.
\end{abstract}

Keywords: amphibious, navigation system, prototype, spy robot

\begin{abstract}
ABSTRAK
Robot memiliki peranan penting dalam segala aspek kehidupan termasuk bidang militer. Tujuan pembuatan proyek akhir ini adalah untuk membangun perangkat keras dan perangkat lunak robot serta mengetahui unjuk kerja robot. Metode yang digunakan dalam pembuatan proyek akhir terdiri dari identifikasi dan analisis kebutuhan, perancangan dan pembuatan hardware dan software, serta pengujian. Hasil unjuk kerja ASRO yaitu, gaya apung robot lebih besar dari berat benda, yaitu $\mathrm{Fa}=22,808 \mathrm{~N}$ dan $\mathrm{W}=15,696 \mathrm{~N}$ atau $\mathrm{Fa}>\mathrm{W}$ sehingga membuat robot mengapung saat beroperasi di medan air. Jangkauan maksimum sistem kontrol robot adalah sejauh 0-30 meter tanpa halangan dan 0- 15 meter dengan halangan, sedangkan pada sistem monitoring adalah sejauh 0-75 meter tanpa halangan dan 0-30 meter dengan halangan. Sistem navigasi robot memiliki persentase keakuratan pembacaan $93,3 \%$ dan persentase respon rata-rata robot saat berputar $90^{\circ}$ adalah $100 \%$, berputar $180^{\circ}$ adalah $100 \%$, dan berputar $270^{\circ}$ adalah $100 \%$.
\end{abstract}

Kata kunci: amfibi, sistem navigasi, prototipe, robot pengintai

\section{PENDAHULUAN}

Robot adalah suatu alat mekanik yang saat ini memegang peranan penting dalam segala aspek kehidupan, yaitu untuk membantu manusia dalam melakukan suatu pekerjaan seperti tugas fisik yang membutuhkan tenaga ekstra kuat dan berbahaya. Selain itu, robot saat ini juga dapat dioperasikan dengan kendali jarak jauh, sehingga pengoperasian robot dapat lebih efektif serta dibekali dengan sensor untuk memperoleh informasi terhadap lingkungan sekitar. Robot berasal dari kata robota yang dalam bahasa ceko (chech) berarti budak atau pekerja" [1]. Al-Jazari (1136-1206) merupakan penemu robot pertama dengan robot musik yang bekerja dengan hydraulic switching [2], [3].

Robot memiliki banyak sekali manfaat dan penerapan yang sangat luas, seperti pada bidang kemiliteran yang dapat difungsikan untuk melakukan tugas yang sulit dikerjakan oleh manusia, yaitu untuk melakukan pengintaian daerah berbahaya di area militer. Keunggulan robot pengintai yaitu, selain dapat di kontrol dari 
jarak yang jauh, robot juga memiliki kamera yang digunakan untuk menangkap data berupa gambar sehingga dapat melakukan pemantauan secara langsung lingkungan sekitar robot beroperasi. Selain itu, robot juga dibekali oleh sebuah sistem yang dapat memberikan informasi tentang arah mata angin sebagai penunjuk arah. Beberapa pengembangan robot pengintai yang sudah dikembangkan diantaranya adalah: (1) robot amfibi untuk sistem monitoring goronggorong [4]; (2) robot amfibi di lingkungan tambang [5]; (3) RHex robot yang mampu bergerak di daratan dan lautan [6]; robot amfibi untuk monitoring limbah cair pada sungai [7]; dan masih terdapat penelitian sebelumnya yangn tidak disebutkan dalam artikel ini.

Alat pertahanan Negara Kesatuan Republik Indonesia (NKRI), yaitu Tentara Nasional Indonesia (TNI), bertugas melaksanakan kebijakan pertahanan negara untuk menegakkan kedaulatan negara, mempertahankan keutuhan wilayah, dan melindungi keselamatan bangsa, menjalankan operasi militer untuk perang dan operasi militer selain perang, serta ikut secara aktif dalam tugas pemeliharaan perdamaian regional dan internasional [8]. Komando Operasi Khusus (Koopssus) TNI sebagai pasukan elit TNI yang baru memiliki tugas yang berkaitan langsung dengan penanggulangan terorisme, dimana $80 \%$ kekuatannya digunakan untuk melakukan pengintaian [9]. Dilain pihak, untuk mendukung pelaksanaan tugas di lapangan, TNI memiliki pesawat tanpa awak UAV CH-4 yang salah satunya bertugas melakukan pengintaian target sasaran [10]. Pengembangan robot amfibi untuk pengintaian di dunia militer telah dikembangkan di korps marinir [11].

Berpijak pada uraian diatas, maka peneliti bermaksud untuk mengembangkan suatu prototipe robot amfibi. Artikel ini memaparkan mengenai pengembangan prototipe robot amfibi yang sesuai kebutuhan TNI melakukan pengintaian dan menjelaskan hasil pengujian dari pengembangan prototipe robot amfibi tersebut. Perbedaan mendasar mengenai prototipe robot amfibi yang dikembangkan dalam penelitian ini dengan yang sebelumnya adalah terkait pengimplementasian untuk keperluan pengintaian TNI dengan pendekatan robot amfibi yang memiliki navigasi arah berbasis kompas.

\section{METODE}

Tabel 1. Identifikasi Kebutuhan

\begin{tabular}{|c|c|c|}
\hline Fungsi & Komponen & Spesifikasi \\
\hline Catu & Baterai Li-Po & $3 \mathrm{cell}, 1800 \mathrm{mAh}$ \\
\hline \multirow[t]{2}{*}{ daya } & Baterai Li-Po & 2 cell, $1000 \mathrm{mAh}$ \\
\hline & DC-DC Step Down & XL4005 \\
\hline \multirow[t]{4}{*}{ Input } & Stik PS2 & Frekuensi 2,4 GHz \\
\hline & Wireless & \\
\hline & Sensor Kompas & 3 Axis \\
\hline & Kamera FPV & 5,8 GHz 40 Channel \\
\hline \multirow[t]{2}{*}{ Proses } & Mikrokontroler & Arduino Uno R3 \\
\hline & Motor Driver & L298N \\
\hline \multirow[t]{5}{*}{ Output } & Motor DC & $630 \mathrm{RPM}, \pm 4 \mathrm{Kg}$ \\
\hline & Motor Servo & SG90, MG90, MG996 \\
\hline & LED & 3 Watt \\
\hline & Buzzer & $5 \mathrm{~V}$ \\
\hline & $\begin{array}{l}\text { Receiver Kamera } \\
\text { FPV }\end{array}$ & ROTG \\
\hline Lain- & VR Box & Shinecon \\
\hline lain & Box Panel & $15 \mathrm{~cm} \mathrm{x} 10 \mathrm{~cm}$ \\
\hline
\end{tabular}

Metode pengembangan yang digunakan peneliti dalam pengembangan prototipe robot amfibi terdiri atas beberapa tahapan, yaiatu: (1) identifikasi dan analisis kebutuhan komponen; (2) perancangan; (3) implementasi hardware dan software; dan (4) pengujian. Identifikasi kebutuhan pengembangan perangkat ini adalah ditujukan untuk pengembangan prototipe robot amfibi pengintai dengan tampilan orang pertama, seperti penglihatan robot saat beroperasi (first person view) dan sistem navigasi berbasis sensor kompas yang diharapkan dapat membantu Tentara Nasional Indonesia (TNI) untuk menjalankan tugas yang membutuhkan pengintaian dalam menjaga kedaulatan Negara Kesatuan Republik Indonesia (NKRI). ASRO (Amphibious Spy Robot) merupakan robot pengintai untuk bidang militer yang dapat melintasi dua medan, yaitu daratan dan perairan yang juga dibekali dengan sensor kompas sebagai sistem navigasi saat robot beroperasi. Identifikasi kebutuhan kertujuan untuk menentukan kebutuhan komponen yang 
diperlukan dalam pembuatan robot. Tabel 1 menyajikan identifikasi kebutuhan untuk pengembangan robot dalam penelitian ini.

Setelah melakukan identifikasi kebutuhan pengembangan dan analisa kebutuhan komponen, maka dilakukan perancangan. Gambar 1 menyajikan blok diagram sistem. Blok diagram sistem keseluruhan dari robot terdiri dari empat blok yang meliputi blok catu daya, blok input, blok process, dan blok output.

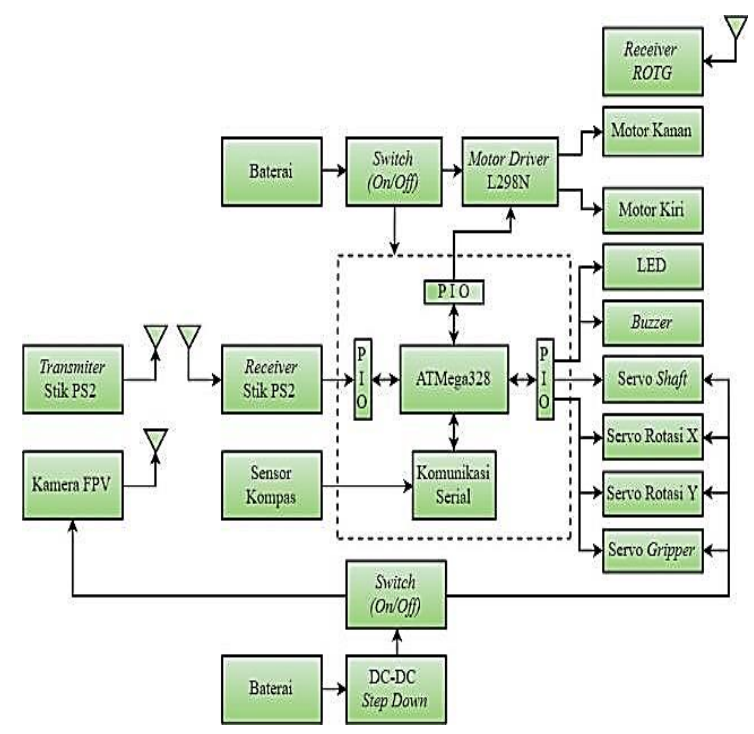

Gambar 1. Blok Diagram Sistem

Perancangan ASRO (Amphibious Spy Robot): prototipe robot amfibi pengintai dengan first person view dan sistem navigasi berbasis sensor kompas menggunakan arduino uno R3 dengan pin dan fungsi yang akan dijelaskan pada Tabel 2. Pembuatan robot terdiri dari perancangan hardware dan software. Perancangan hardware dibagi menjadi dua bagian, yaitu desain mekanik dan elektronik. Gambar 2 adalah rancangan mekanik yang terdiri dari kerangka dan 3D. Gambar 3 merupakan Mekanik Utama Robot Rancangan 3D diperlukan sebagai acuan. Rancangan kerangka diperlukan untuk membangun mekanik robot dengan ukuran dan dudukan komponen agar dapat presisi dan pergerakan robot dapat berjalan sempurna tanpa mengalami kendala. Rancangan kerangka yang telah dibuat kemudian di potong menggunakan mesin pemotong laser.
Tabel 2. Pin Arduino Uno R3 yang digunakan

\begin{tabular}{|c|c|c|c|}
\hline Pin & $\begin{array}{l}\text { Pin } \\
\text { No }\end{array}$ & $\begin{array}{l}\text { Tipe } \\
\text { Pin }\end{array}$ & Fungsi \\
\hline \multirow{13}{*}{ Digital } & 2 & $\mathrm{I} / \mathrm{O}$ & Servo poros lengan robot \\
\hline & 3 & $\mathrm{I} / \mathrm{O}$ & IN1 motor dirver L298N \\
\hline & 4 & $\mathrm{I} / \mathrm{O}$ & Servo rotasi Y lengan robot \\
\hline & 5 & $\mathrm{I} / \mathrm{O}$ & IN2 motor dirver L298N \\
\hline & 6 & $\mathrm{I} / \mathrm{O}$ & IN3 motor dirver L298N \\
\hline & 7 & $\mathrm{I} / \mathrm{O}$ & Servo rotasi $\mathrm{X}$ lengan robot \\
\hline & 8 & $\mathrm{I} / \mathrm{O}$ & Servo gripper lengan robot \\
\hline & 9 & $\mathrm{I} / \mathrm{O}$ & IN4 motor dirver L298N \\
\hline & 10 & $\mathrm{I} / \mathrm{O}$ & Pin Clock receiver stik PS2 \\
\hline & 11 & $\mathrm{I} / \mathrm{O}$ & Pin Attention receiver stik PS2 \\
\hline & 12 & $\mathrm{I} / \mathrm{O}$ & Pin Command receiver stik PS2 \\
\hline & 13 & $\mathrm{I} / \mathrm{O}$ & Pin Data receiver stik PS2 \\
\hline & $\mathrm{A} 2$ & $\mathrm{I} / \mathrm{O}$ & Buzzer \\
\hline \multirow{3}{*}{ Analog } & A3 & $\mathrm{I} / \mathrm{O}$ & LED \\
\hline & A4 & SDA & SDA Sensor Kompas \\
\hline & A5 & SCL & SDL Sensor Kompas \\
\hline
\end{tabular}

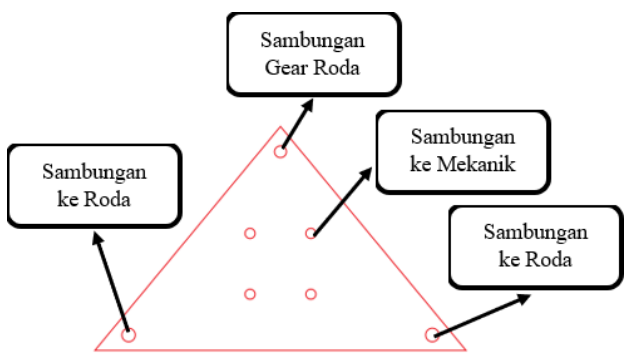

Gambar 2. Sambungan Mekanik Roda

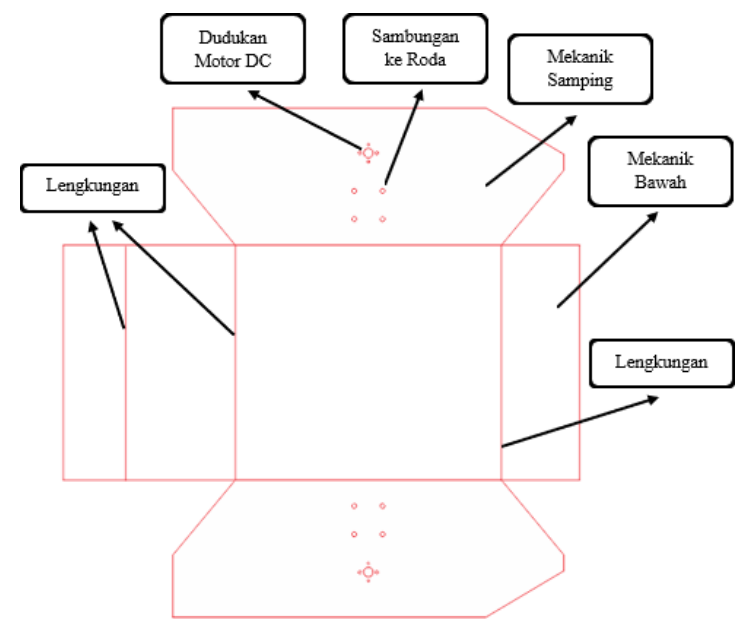

Gambar 3. Mekanik Utama Robot

Rancangan 3D diperlukan sebagai acuan dalam membangun suatu alat, dalam hal ini robot amfibi pengintai. Terdapat beberapa part untuk kerangka robot dan part untuk robot lengan yang kemudian dilakukan assembly menjadi satu kesatuan mekanik. Rancangan 3D robot 
disajikan pada Gambar 4 (a). Sistem elektronik ASRO terdiri dari beberapa komponen, Arduino Uno R3, stick PS2 wireless, motor driver L298N, motor DC, motor servo, sensor kompas, LED, dan buzzer. Gambar 4(b) merupakan desain dari rangkaian elektronik menggunakan software Proteus.

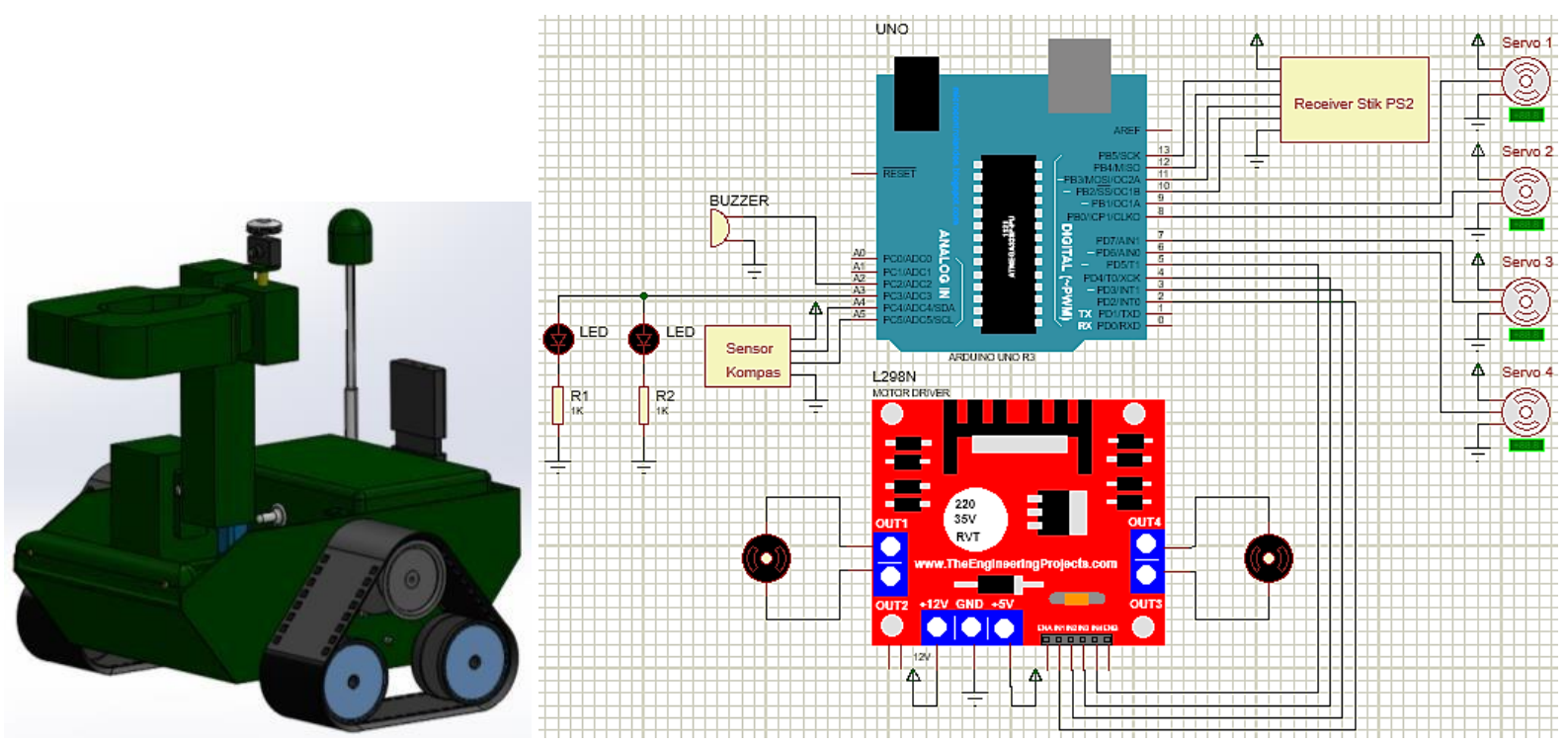

Gambar 4. (a) Rancangan 3D Robot, (b) Skema Elektronik

Perancangan software merupakan pembuatan sistem dengan membuat listing program yang akan dimasukkan ke dalam chip ATMega328 Arduino Uno. Pada tahap perancangan, software yang digunakan adalah Arduino IDE dengan menggunakan bahasa pemograman C. Setelah perancangan dilakukan, maka dilakukan tahap berikutnya, yaitu implementasi dan pengujian untuk mengetahui kinerja dari alat.

\section{HASIL DAN PEMBAHASAN}

Realisasi dalam pengimplentasian rancangan berbentuk robot pengintai untuk bidang militer dengan kendali jarak jauh (wireless) yang dibekali kamera FPV. Robot pengintai ini bergerak menggunakan motor DC $630 \mathrm{RPM}$ dengan torsi $\pm 4 \mathrm{Kg}$. Robot juga dibekali dengan robot lengan yang berfungsi untuk menyingkirkan halangan saat menjalankan tugas dan menyusuri area musuh lebih dalam. Selain itu, terdapat sensor kompas untuk membaca arah mata angin pada sistem navigasi agar mengetahui arah utara, barat, selatan, dan timur. Setelah robot berhasil direalisasikan, maka dilanjutkan dengan pengujian.

Pengujian dilakukan untuk memperoleh data dengan menggunakan dua pengujian, yaitu pengujian fungsional dan pengujian unjuk kerja. Pengujian fungsional dilakukan dengan cara menguji setiap rangkaian berdasarkan karakterisitik dan fungsinya masing-masing sesuai dengan rangkaian dan software yang meliputi pengujian tegangan arduino uno R3 dan DC-DC step down, arus pada robot, catu daya, driver motor L298N, motor DC, lengan robot, sensor kompas, lintasan robot, dan kecepatan robot. Pengujian unjuk kerja dilakukan untuk mengetahui bahwa robot beserta sistem dapat bekerja dengan baik secara keseluruhan. Pengujian tegangan bertujuan untuk mengetahui perubahan nilai tegangan saat sebelum dan setelah menerima beban pada Arduino Uno R3 dan DC-DC Step Down. Hasil pengujian tegangan disajikan pada Tabel 3 dan Tabel 4. 
Tabel 3. Pengujian Tegangan Tanpa Beban

\begin{tabular}{llcccc}
\hline No & Pengukuran & V-Out & $\begin{array}{c}\text { Alat } \\
\text { Ukur }\end{array}$ & Selisih & $\begin{array}{c}\text { Error } \\
(\%)\end{array}$ \\
\hline 1. & Arduino Uno & $3,3 \mathrm{~V}$ & $3,28 \mathrm{~V}$ & $0,02 \mathrm{~V}$ & $0,6 \%$ \\
& R3 & $5 \mathrm{~V}$ & $5,01 \mathrm{~V}$ & $0,01 \mathrm{~V}$ & $0,2 \%$ \\
2. & $\begin{array}{l}\text { DC-DC } \\
\text { Step Down }\end{array}$ & $5 \mathrm{~V}$ & $5 \mathrm{~V}$ & $0 \mathrm{~V}$ & $0 \%$ \\
\hline
\end{tabular}

Tabel 4. Pengujian Tegangan dengan Beban

\begin{tabular}{llcccc}
\hline No & Pengukuran & V-Out & $\begin{array}{c}\text { Alat } \\
\text { Ukur }\end{array}$ & Selisih & $\begin{array}{c}\text { Error } \\
(\%)\end{array}$ \\
\hline 1. & Arduino Uno & $3,3 \mathrm{~V}$ & $3,61 \mathrm{~V}$ & $0,31 \mathrm{~V}$ & $9,4 \%$ \\
& R3 & $5 \mathrm{~V}$ & $5,02 \mathrm{~V}$ & $0,02 \mathrm{~V}$ & $0,4 \%$ \\
2. & $\begin{array}{l}\text { DC-DC } \\
\text { Step Down }\end{array}$ & $5 \mathrm{~V}$ & $5 \mathrm{~V}$ & $0 \mathrm{~V}$ & $0 \%$ \\
\hline
\end{tabular}

Tabel 3 dan Tabel 4 merupakan hasil pengujian tegangan. Pengujian tegangan tanpa beban memiliki persentase error pada pin 3,3V sebesar 0,6\% dan pin 5V sebesar 0,2\% Pada DCDC step down persentase error 0\%. Pengujian dengan beban memiliki persentase error pada pin $3,3 \mathrm{~V}$ dan pin $5 \mathrm{~V}$ masing-masing sebesar 9,4\% dan 04\%, serta persentase error DC- DC step down sebesar 0\%. Setelah pengujian tegangan dilakkan pengajuan arus. Pengujian arus bertujuan untuk mengetahui berapa arus yang mengalir pada rangkaian untuk mengoperasikan robot yang tersaji pada Tabel 5 .

Tabel 5. Pengujian Arus pada Robot

\begin{tabular}{|c|c|c|c|}
\hline & \multicolumn{3}{|c|}{ Baterai (2s $1000 \mathrm{mAh})$ Baterai (3s $1800 \mathrm{mAh})$} \\
\hline No & Kondisi & Arus Kondisi & Arus \\
\hline 1 & Standby & 0,58 A Standby & $0,13 \mathrm{~A}$ \\
\hline 2 & $\begin{array}{l}\text { Servo } \\
\text { shaft operasi }\end{array}$ & $\begin{array}{l}0,45 \text { A Motor } \\
\text { operasi }\end{array}$ & $0,47 \mathrm{~A}$ \\
\hline 3 & Servo rotasi & & \\
\hline & Xoperasi $0^{\circ}$ & $\begin{array}{c}\text { 0,56 A Navigasi } \\
\text { operasi }\end{array}$ & $0,44 \mathrm{~A}$ \\
\hline 4 & Servo rotasi & & \\
\hline & Xoperasi $180^{\circ}$ & $0,58 \mathrm{~A}-$ & - \\
\hline 5 & Servo rotasi & & \\
\hline & Yoperasi & $0,42 \mathrm{~A}-$ & - \\
\hline 6 & $\begin{array}{l}\text { Servo gripper } \\
\text { buka }\end{array}$ & $0,45 \mathrm{~A}-$ & - \\
\hline 7 & $\begin{array}{l}\text { Servo gripper } \\
\text { tutup }\end{array}$ & $0,53 \mathrm{~A}-$ & - \\
\hline
\end{tabular}

Setelah nilai arus diketahui, selanjutnya dapat menghitung daya tahan baterai berdasarkan jenis baterai dan beban yang diperoleh oleh masing-masing baterai. Dalam hal ini, terdapat dua baterai yang digunakan yaitu $2 \mathrm{~s}$ dan $3 \mathrm{~s}$ dengan perhitungan sebagai seperti pada Tabel 6.

Tabel 6. Perhitungan daya tahan baterai

\begin{tabular}{|c|c|c|c|c|c|}
\hline \multirow{2}{*}{ Baterai } & \multirow{2}{*}{ Tegangan } & \multirow{2}{*}{ Baterai } & \multirow{2}{*}{ Sumber daya baterai } & \multicolumn{2}{|c|}{ Arus standby } \\
\hline & & & & Konsumsi daya & Daya tahan baterai \\
\hline Baterai 2 & VKapasitas & $1 \mathrm{Ah}$ & $\begin{array}{l}=\mathrm{V} \times \text { Kapasitas Batt } \\
=8,4 \mathrm{~V} \times 1 \mathrm{Ah}=8,4 \mathrm{Wh}\end{array}$ & $\begin{array}{l}=0,58 \mathrm{~A} \times 8,4 \mathrm{~V} \\
=4,872 \mathrm{~W}\end{array}$ & $\begin{array}{l}=8,4 \mathrm{Wh} / 4,872 \mathrm{~W} \\
=1,72 \mathrm{jam}\end{array}$ \\
\hline Baterai 3 & 6 V Kapasitas & $1,8 \mathrm{Ah}$ & $\begin{array}{l}=\mathrm{V} \times \text { Kapasitas Batt } \\
=12,6 \mathrm{~V} \times 1,8 \mathrm{Ah}=22,68 \mathrm{Wh}\end{array}$ & $\begin{array}{l}=0,13 \mathrm{~A} \times 12,6 \mathrm{~V} \\
=4,872 \mathrm{~W}\end{array}$ & $\begin{array}{l}=22,68 \mathrm{Wh} / 1,638 \mathrm{~W} \\
=13,85 \mathrm{jam}\end{array}$ \\
\hline
\end{tabular}

Tabel 7. Pengujian Catu Daya

\begin{tabular}{ccccr}
\hline \multicolumn{3}{c}{ Baterai (2s $1000 \mathrm{mAh})$} & \multicolumn{2}{c}{ Baterai (3s $1800 \mathrm{mAh})$} \\
No Tegangan & Waktu & Tegangan & Waktu \\
\hline 1. & $7,75 \mathrm{~V}$ & 0 Menit & $12,40 \mathrm{~V}$ & 0 Menit \\
2. & $7,71 \mathrm{~V}$ & 3 Menit & $12,29 \mathrm{~V}$ & 15 Menit \\
3. & $7,67 \mathrm{~V}$ & 6 Menit & $12,21 \mathrm{~V}$ & 30 Menit \\
4. & $7,62 \mathrm{~V}$ & 9 Menit & $12,07 \mathrm{~V}$ & 55 Menit \\
5. & $7,58 \mathrm{~V}$ & 12 Menit & $12,00 \mathrm{~V}$ & 70 Menit \\
6. & $7,53 \mathrm{~V}$ & 13 Menit & $11,81 \mathrm{~V}$ & 100 Menit \\
7. & $7,48 \mathrm{~V}$ & 14 Menit & $11,74 \mathrm{~V}$ & 130 Menit \\
8. & $7,40 \mathrm{~V}$ & 15 Menit & $11,60 \mathrm{~V}$ & 160 Menit \\
\hline
\end{tabular}

Tabel 6 menunjukkan bahwa secara teori, kondisi robot saat beroperasi mempengaruhi variasi daya tahan baterai, baik $2 \mathrm{~s}$ maupun $3 \mathrm{~s}$. Lama daya tahan baterai dalam pengoperasian robot mengacu pada perhitungan tersebut.
Pengujian selanjutnya adalah pengujian catu daya. Pengujian tersebut bertujuan untuk mengetahui seberapa lama daya tahan baterai dalam mengoperasikan robot.

Tabel 7 merupakan hasil pengujian catu daya. Dari hasil data pengujian tersebut, dapat disimpulkan bahwa waktu operasi robot adalah sekitar 15 menit untuk baterai 2 s sebagai catu daya robot lengan serta kamera FPV dan 160 menit untuk baterai 3s sebagai catu daya sistem dan penggerak robot. Dengan membandingkan hasil perhitungan berdasarkan Tabel 5 dengan pengujian asli diketahui bahwa terdapat perbedaan dikarenakan saat robot beroperasi, arus yang mengalir pada robot terkadang mengalami kenaikan dan penurunan sehingga 
daya tahan baterai mengalami perubahan. Pengujian rangkaian motor driver L298N untuk mengetahui apakah rangkaian driver yg digunakan dapat bekerja dengan baik. Rangkaian yang digunakan sebagai motor driver adalah rangkaian yang menggunakan IC L298. Hasil pengujian rangkaian driver L298N disajikan pada Tabel 8 .

Tabel 8. Pengujian Rangkaian Motor Driver L298N

\begin{tabular}{cccc}
\hline Enable & Input 1 & Input 2 & Kondisi Motor \\
\hline \multirow{3}{*}{ Ven $=0$ Volt } & 0 Volt & 0 Volt & Diam \\
& 0 Volt & 5 Volt & Diam \\
& 5 Volt & 0 Volt & Diam \\
& 5 Volt & 5 Volt & Diam \\
Ven $=5$ Volt & 0 Volt & 0 Volt & Diam \\
& 0 Volt & 5 Volt & Putar Kiri \\
& 5 Volt & 0 Volt & Putar Kanan \\
& 5 Volt & 5 Volt & Diam \\
\hline
\end{tabular}

Ketika enable motor driver diberikan kondisi $0 \mathrm{~V}$, maka kombinasi yang diberikan pada input 1 dan input 2 tidak berpengaruh terhadap kondisi motor, yaitu kondisi motor akan tetap diam. Sedangkan apabila enable diberikan tegangan $5 \mathrm{~V}$, maka kombinasi pada input 1 dan input 2 memiliki pengaruh. Ketika salah satu input mendapatkan tegangan masukan $5 \mathrm{~V}$, kondisi motor akan berputar, akan tetapi saat input 1 dan input 2 mendapatkan tegangan $5 \mathrm{~V}$ secara bersamaan, kondisi motor tidak berputar. Pengujian putaran motor DC yang disajikan pada Tabel 9 bertujuan untuk mengetahui kesesuaian putaran motor DC dan gerakan yang diinginkan. Tabel 9 menunjukkan bahwa tiap servo untuk menggerakkan shaft, rotasi $\mathrm{X}$, rotasi $\mathrm{Y}$, dan gripper memiliki waktu tempuh yang bervariasi, dikarenakan beban yang diperoleh berbeda, Kemudian, beban yang dapat dibawa oleh lengan adalah 40 gr.

Pengujian keakuratan sensor kompas yang disajikan pada Tabel 10, bertujuan untuk mengetahui tingkat keakuratan sensor dengan pembacaan nilai derajat kompas sebenarnya. Pembacaan sensor kompas memiliki perbedaan dengan sudut arah mata angin disebabkan oleh berbagai faktor, salah satunya lingkungan karena mempengaruhi pembacaan sensor terhadap medan magnet bumi. Perbandingan antara sudut arah mata angin dengan sensor kompas diperoleh rata-rata selisih sekitar $14,5^{\circ}$, sehingga akurasi rata-rata dari hasil pembacaan sensor yaitu sebesar 93,3\%. Dari hasil pengujian tersebut dapat disimpulkan bahwa sensor cukup baik dalam melakukan pembacaan.

Tabel 9. Pengujian Robot Lengan

\begin{tabular}{|c|c|c|c|c|}
\hline Servo - n & $\begin{array}{l}\text { Rentang } \\
\text { Pergerakan }\end{array}$ & $\begin{array}{c}\text { Waktu } \\
\text { (Min-Max) }\end{array}$ & $\begin{array}{c}\text { Waktu } \\
\text { (Max-Min) }\end{array}$ & $\begin{array}{l}\text { Be- } \\
\text { ban }\end{array}$ \\
\hline $\begin{array}{l}\text { Servo } 1 \\
\text { (Shaft) }\end{array}$ & $95^{\circ}-163^{\circ}$ & $0,69 \mathrm{~s}$ & $0,54 \mathrm{~s}$ & - \\
\hline \multirow{3}{*}{$\begin{array}{c}\text { Servo } 2 \\
(\text { Rotasi X) }\end{array}$} & $0^{\mathrm{O}}-90^{\mathrm{O}}$ & $0,17 \mathrm{~s}$ & $0,16 \mathrm{~s}$ & - \\
\hline & $90^{\circ}-180^{\circ}$ & $0,28 \mathrm{~s}$ & $0,25 \mathrm{~s}$ & - \\
\hline & $0^{\mathrm{O}}-180^{\mathrm{O}}$ & $0,50 \mathrm{~s}$ & $0,47 \mathrm{~s}$ & - \\
\hline $\begin{array}{c}\text { Servo } 3 \\
\text { (Rotasi Y) }\end{array}$ & $10^{\mathrm{O}}-88^{\mathrm{O}}$ & $0,32 \mathrm{~s}$ & $0,27 \mathrm{~s}$ & - \\
\hline $\begin{array}{l}\text { Servo } 4 \\
\text { (Gripper) }\end{array}$ & $45^{\circ}-90^{\circ}$ & $0,24 \mathrm{~s}$ & $0,16 \mathrm{~s}$ & $40 \mathrm{gr}$ \\
\hline
\end{tabular}

Tabel 10. Pengujian Keakuratan Sensor Kompas

\begin{tabular}{|c|c|c|c|c|c|}
\hline No & Arah & Sudut & $\begin{array}{l}\text { Sensor } \\
\text { Kompas }\end{array}$ & Selisih & $\begin{array}{c}\text { Akurasi } \\
(\%)\end{array}$ \\
\hline 1. & Utara & $0^{\circ} / 360^{\circ}$ & $340^{\circ}$ & $20^{\circ}$ & $95 \%$ \\
\hline 2. & Timur & $90^{\circ}$ & $87^{\circ}$ & $3^{0}$ & $96,7 \%$ \\
\hline 3. & Selatan & $180^{\circ}$ & $210^{\circ}$ & $30^{\circ}$ & $83,4 \%$ \\
\hline 4. & Barat & $270^{\circ}$ & $275^{\circ}$ & $5^{0}$ & $98,15 \%$ \\
\hline \multicolumn{4}{|c|}{ Rata-rata } & $14,5^{\circ}$ & $93,3 \%$ \\
\hline
\end{tabular}

Pengujian lintasan robot pada Tabel 11 bertujuan untuk mengetahui sejauh mana robot dapat berjalan pada berbagai macam lintasan. Berdasarkan hasil pengujian dapat disimpulkan bahwa robot dapat beroperasi di berbagai lintasan. Robot pada lintasan porselin, keramik, semen dan tanah memiliki pergerakan yang baik. Akan tetapi, pada lintasan tanah untuk pergerakan belok kanan dan belok kiri kurang baik, dan untuk lintasan tanjakan dapat melintas dengan baik dengan syarat sudut kemiringan $10^{\circ}$. Pengujian kecepatan robot pada Tabel 12 bertujuan untuk mengetahui kecepatan daya laju robot saat beroperasi di medan darat dan air. Jarak tempuh pada pergerakan robot maju di medan darat diperoleh rata-rata $79 \mathrm{~cm} / \mathrm{s}$ dan pergerakan robot mundur diperoleh rata-rata sejauh $73 \mathrm{~cm} / \mathrm{s}$. Kemudian pada medan air dengan pergerakan robot maju diperoleh ratarata jarak tempuh adalah $21 \mathrm{~cm} / \mathrm{s}$ dan pergerakan robot mundur diperoleh rata- rata jarak tempuh sejauh $18 \mathrm{~cm} / \mathrm{s}$. 
Tabel 11. Pengujian Lintasan Robot

\begin{tabular}{ccccc}
\hline \multirow{2}{*}{ No } & Jenis Lintasan & $\begin{array}{c}\text { Pergerakan Robot } \\
\text { Maju } \\
\text { Mundur }\end{array}$ & $\begin{array}{c}\text { Kanan } \\
\text { Kiri }\end{array}$ & Syarat \\
\hline 1. & Lintasan Porselin & Baik & Baik & - \\
2. & Lintasan Keramik & Baik & Baik & - \\
3. & Lintasan Semen & Baik & Baik & - \\
4. & Lintasan Tanah & Baik & Kurang & Tidak \\
& & & Baik ada batu \\
5. & Lintasan Tanjakan & Baik & Baik & $10^{\circ}$ \\
\hline
\end{tabular}

Tabel 12. Pengujian Kecepatan Robot

\begin{tabular}{|c|c|c|c|c|}
\hline No & $\begin{array}{l}\text { Jenis } \\
\text { Medan }\end{array}$ & $\begin{array}{l}\text { Uji } \\
\mathrm{Ke}-\end{array}$ & $\begin{array}{c}\text { Pergerakan } \\
\text { Robot }\end{array}$ & $\begin{array}{c}\text { Jarak } \\
\text { Tempuh } \\
\end{array}$ \\
\hline \multirow{5}{*}{1.} & \multirow{5}{*}{ Darat } & 1 & Maju 1 detik & $80 \mathrm{~cm}$ \\
\hline & & 2 & Maju 1 detik & $83 \mathrm{~cm}$ \\
\hline & & 3 & Maju 1 detik & $74 \mathrm{~cm}$ \\
\hline & & & Rata-rata & $79 \mathrm{~cm}$ \\
\hline & & 1 & Mundur 1 detik & $69 \mathrm{~cm}$ \\
\hline \multirow{3}{*}{2.} & \multirow{3}{*}{ Darat } & 2 & Mundur 1 detik & $74 \mathrm{~cm}$ \\
\hline & & 3 & Mundur 1 detik & $75 \mathrm{~cm}$ \\
\hline & & & Rata-rata & $73 \mathrm{~cm}$ \\
\hline \multirow{4}{*}{3.} & \multirow{4}{*}{ Air } & 1 & Maju 1 detik & $20 \mathrm{~cm}$ \\
\hline & & 2 & Maju 1 detik & $22 \mathrm{~cm}$ \\
\hline & & 3 & Maju 1 detik & $21 \mathrm{~cm}$ \\
\hline & & & Rata-rata & $21 \mathrm{~cm}$ \\
\hline \multirow{4}{*}{4.} & \multirow{4}{*}{ Air } & 1 & Mundur 1 detik & $18 \mathrm{~cm}$ \\
\hline & & 2 & Mundur 1 detik & $17 \mathrm{~cm}$ \\
\hline & & 3 & Mundur 1 detik & $19 \mathrm{~cm}$ \\
\hline & & & Rata-rata & $18 \mathrm{~cm}$ \\
\hline
\end{tabular}

Pengujian gaya apung robot yang disajikan pada Tabel 13 bertujuan untuk mengetahui kemampuan robot untuk beroperasi di medan air. Pada robot terdapat dua mekanik yang digunakan sebagai gaya apung robot, yaitu pada mekanik apung dan box panel. Berikut akan dijelaskan perhitungan volume untuk mengetahui gaya apung dari kedua mekanik tersebut untuk bisa menghasilkan gaya apung dan mengangkat robot agar dapat mengapung di air.

Pada Gambar 7(a) dan Gambar 7(b) merupakan desain bangun ruang mekanik apung dengan alasnya berbentuk trapezium dengan nilai $\mathrm{b} 1=17 \mathrm{~cm}, \mathrm{~b} 2=25 \mathrm{~cm}, \mathrm{~h}=5 \mathrm{~cm}$, dan $\mathrm{H}=$ $15 \mathrm{~cm}$. Gambar 7(c) merupakan desain bangun ruang mekanik box panel dengan ukuran $\mathrm{p}=10$ $\mathrm{cm}, 1=15 \mathrm{~cm}$, dan $\mathrm{t}=5 \mathrm{~cm}$. Nilai volume kedua mekanik digunakan untuk mendefinisikan massa jenis (dalam $\mathrm{kg} / \mathrm{m}^{3}$ ) dari fluida. Fluida air memiliki massa jenis sekitar $1000 \mathrm{~kg} / \mathrm{m}^{3}$. Dalam pengujian, robot bekerja pada air yang statis, sehingga kita dapat menganggap bahwa satusatunya gaya ke bawah yang bekerja pada fluida dan benda adalah gaya gravitasi umum, yaitu $9,81 \mathrm{~N} / \mathrm{kg}$. Tabel 14 menunjukkan hasil beberapa perhitungan diatas, yaitu: (1) volume dari bangun mekanik apung robot; (2) volume bangun mekanik box panel; (3) gaya apung robot; dan (4) perbandingan gaya apung robot dengan berat benda yang mendorong robot ke bawah. Jika gaya apung lebih besar dari berat benda, maka benda akan mengapung. Sebaliknya, jika berat benda lebih besar daripada gaya apung, benda akan tenggelam. Jika besarnya sama, benda dikatakan melayang. Berdasarkan hasil perhitungan menunjukkan bahwa gaya apung lebih besar dari berat benda, yaitu $\mathrm{Fa}=22,808 \mathrm{~N}$ dan $\mathrm{W}=15,696 \mathrm{~N}$ atau $\mathrm{Fa}$ $>\mathrm{W}$ sehingga membuat robot mengapung saat berada di medan air.

Tabel 13. Pengujian Gaya Apung Robot

\begin{tabular}{ccc}
\hline No & Lokasi & Foto \\
KPLT FT UNY \\
( Mengapung)
\end{tabular}

Tabel 14. Perhitungan volume dan gaya apung ( V1+V2=0,001575 $\mathrm{m}^{3}+0,0075 \mathrm{~m}^{3}=0,009075 \mathrm{~m}^{3}$ )

\begin{tabular}{lccl}
\hline \multicolumn{1}{c}{ Volume robot $(\mathrm{V} 1)$} & Volume box panel $(\mathrm{V} 2)$ & Gaya apung & Berat \\
\hline = Luas alas x tinggi & $=$ panjang $\times$ lebar $\times$ tinggi & $=(\mathrm{V} 1+\mathrm{V} 2) \times \rho \times \mathrm{g}$ & $=$ massa $\times$ gravitasi \\
$=((0.5($ alas $1+$ alas 2$) \times$ tinggi $) \times$ tinggi $=10 \mathrm{~cm} \times 15 \mathrm{~cm} \times 5 \mathrm{~cm}$ & $=\left(009075 \mathrm{~m}^{3}\right) \times 1000 \mathrm{~kg} / \mathrm{m}^{3}$ & $=1.6 \mathrm{~kg} \times 9,81 \mathrm{~m} / \mathrm{s} 2$ \\
$=\left((0.5(17 \mathrm{~cm}+25 \mathrm{~cm}) \times 5 \mathrm{~cm}) \times 15 \mathrm{~cm}=750 \mathrm{~cm}^{3}=0,00075 \mathrm{~m}^{3}\right.$ & $\times 9,81 \mathrm{~N} / \mathrm{kg}$ & $=15.696 \mathrm{~N}$ \\
$=1575 \mathrm{~cm}^{3}=0,001575 \mathrm{~m}^{3}$ & $=22,808 \mathrm{~N}$ & \\
\hline
\end{tabular}




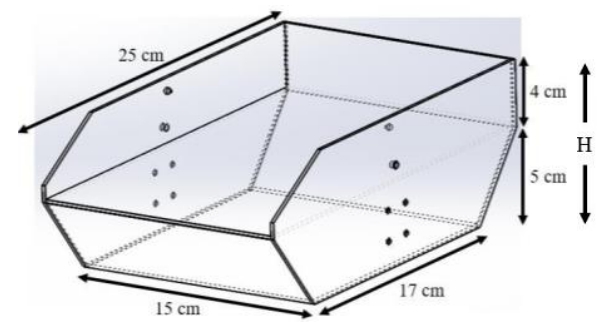

(a)

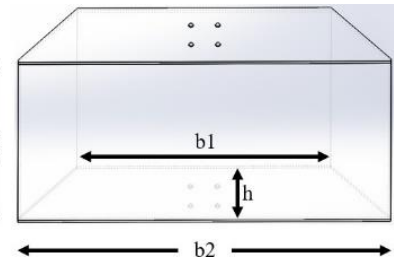

(b)

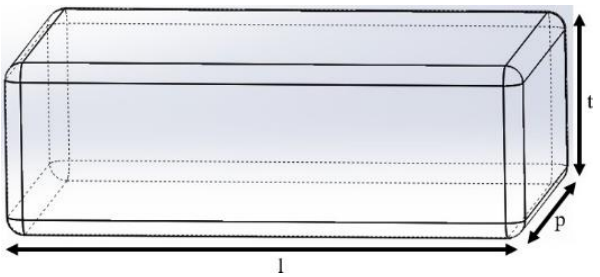

(c)

Gambar 7. (a) Desain Mekanik Apung, (b) Desain Bangun Ruang Mekanik Apung, (c) Desain Bangun Ruang Mekanik Box Panel

Pengujian jangkauan robot pada Tabel 15 bertujuan untuk mengetahui seberapa jauh robot dapat di kontrol dan melakukan monitoring. Jarak optimal pengontrolan pergerakan robot pada kondisi tanpa penghalang adalah 0-30 meter, sedangkan monitoring berjarak 0-75 meter. Kemudian dengan kondisi robot terhalang bangunan atau benda lainnya menunjukkan jarak pengontrolan pergerakan robot adalah 0-15 meter, dan monitoring berjarak 0-30 meter.

Tabel 15. Pengujian Jangkauan Robot

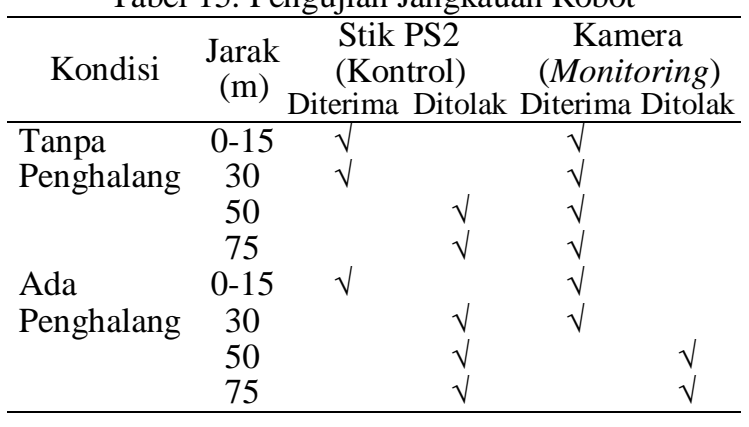

Tabel 16. Pengujian Respon Navigasi Robot

\begin{tabular}{|c|c|c|c|}
\hline \multirow{5}{*}{$\frac{\mathrm{No}}{1 .}$} & Pengujian Ke- & Berputar & Respon \\
\hline & 1 & \multirow{3}{*}{$90^{\circ}$} & Berhasil \\
\hline & 2 & & Berhasil \\
\hline & 3 & & Berhasil \\
\hline & \multicolumn{2}{|c|}{ Persentase Rata-rata } & $100 \%$ \\
\hline \multirow[t]{4}{*}{2.} & 1 & \multirow{3}{*}{$180^{\circ}$} & Berhasil \\
\hline & 2 & & Berhasil \\
\hline & 3 & & Berhasil \\
\hline & \multicolumn{2}{|c|}{ Persentase Rata-rata } & $100 \%$ \\
\hline \multirow[t]{4}{*}{3.} & 1 & \multirow{3}{*}{$270^{\circ}$} & Berhasil \\
\hline & 2 & & Berhasil \\
\hline & 3 & & Berhasil \\
\hline & Persentase & ata-rata & $100 \%$ \\
\hline
\end{tabular}

Pengujian respon navigasi robot seperti disajikan pada Tabel 16 bertujuan untuk mengetahui respon robot dalam menentukan arah dan melakukan navigasi. Respon robot dari posisi awal menuju arah mata angin tujuan dengan berputar terhadap sudut $90^{\circ}, 180^{\circ}$ dan $270^{\circ}$ yang dilakukan sebanyak tiga kali percobaan telah bekerja dengan baik. Dari hasil pengujian didapatkan data bahwa respon ratarata robot saat berputar $90^{\circ}$ adalah $100 \%$, berputar $180^{\circ}$ adalah $100 \%$, dan berputar $270^{\circ}$ adalah $100 \%$.

Hasil keseluruhan menunjukkan robot amfibi memiliki unjuk kerja yang sesuai dengan fungsi pengembangan dalam penelitian ini. Namun demikian, terdapat kebutuhan pengembangan untuk kebutuhan alutsista TNI yang belum dipenuhi. Hal tersebut menjadi salah satu keterbatasan dalam penelitian ini. Analisis merupakan hal yang penting dalam metode pengembangan, dimana analisis komprehensif akan menghasilkan desain yang sesuai kebutuhan [12]. Desain membutuhkan analisis yang mendalam [13]. Penelitian pengembangan selanjutnya perlu melakukan analisis kebutuhan yang lebih mendalam. Pengembangan perangkat untuk penelitian kedepan adalah mengoptimalkan fungsi selain untuk pengintaian, tetapi juga dapat untuk penembakan dan pengeboman [10]. Kemampuan adaptif secara realtime dan penambahan sensor sesuai kebutuhan pada kendaraan tanpa awak dimungkinkan dapat dilakukan menggunakan sistem manajemen lintasan (trajectory management system) [14]. Pengaplikasian sistem tersebut dapat digunakan pada robot amfibi sebagai alutsista TNI yang tidak hanya untuk pengintaian, tapi dapat digunkan untuk penembakan, pengeboman dan kemampuan lain dalam rangka pertahanan negara. 


\section{SIMPULAN}

Berdasarkan hasil pengujian dan pembahasan yang telah dilakukan terhadap ASRO (Amphibious Spy Robot), maka dapat diperoleh kesimpulan sebagai berikut: (1) ASRO (Amphibious Spy Robot) merupakan prototipe robot amfibi pengintai dengan first person view dan sistem navigasi berbasis sensor kompas merupakan robot pengintai untuk bidang militer yang dapat melintasi dua medan, yaitu daratan dan perairan yang juga dibekali dengan sensor kompas sebagai masukan untuk membaca sudut untuk sistem navigasi agar dapat mengetahui arah utara, barat, selatan, dan timur saat robot beroperasi; dan(2) Hasil unjuk kerja dari ASRO yaitu, gaya apung robot lebih besar dari berat benda, yaitu $\mathrm{Fa}=22,808 \mathrm{~N}$ dan $\mathrm{W}=15,696 \mathrm{~N}$ atau $\mathrm{Fa}>\mathrm{W}$ sehingga membuat robot mengapung saat beroperasi di medan air. Jangkauan maksimum sistem kontrol robot adalah sejauh 0-30 meter tanpa halangan dan 015 meter dengan halangan, sedangkan pada sistem monitoring adalah sejauh 0-75 meter tanpa halangan dan 0-30 meter dengan halangan. Sistem navigasi robot memiliki persentase keakuratan pembacaan 93,3\% dan persentase respon rata-rata robot saat berputar $90^{\circ}$ adalah $100 \%$, berputar $180^{\circ}$ adalah $100 \%$, dan berputar $270^{\circ}$ adalah $100 \%$

\section{DAFTAR PUSTAKA}

[1] J. Yusep Nur, Cara Mudah Merakit Robot untuk pemula mengupas tuntas segala hal tentang robot. FlashBooks, 2011.

[2] D. Sayfeddine and A. G. Bulgakov, "Intelligent fuzzy-neural pattern generation and control of a quadrupedal bionic inspection robot," in IOP Conference Series: Materials Science and Engineering, 2017, vol. 177, no. 012010, pp. 16.

[3] L. Romdhane and S. Zeghloul, "Al-Jazari (11361206)," in Distinguished Figures in Mechanism and Machine Science:Their Contributions and Legacies, Part 2, History of Mechanism and Machine Science 7, M. Ceccarelli, Ed. Springer Science+Business Media B.V., 2010, pp. 1-21.

[4] M. Y. Mustar, A. E. Nugraha, A. I. Hidayat, H. Zidni, and R. D. Oktaviani, "Rancang Bangun Robot Amphibi Sebagai Sistem Monitoring Gorong-Gorong," Semesta Tek., vol. 20, no. 2, pp. 139-146, 2017.

[5] A. Maity and S. Majumder, "Design of an Amphibian Exploring Robot," IOP Conf. Ser. Mater. Sci. Eng., vol. 65(1), no. 012015, 2014.

[6] C. Prahacs, A. Saudners, M. K. Smith, D. McMordie, and M. Buehler, "Towards legged amphibious mobile robotics," Proc. Can. Des. Eng. Netw. Conf., 2004.

[7] R. H. Hidayat, "Prototipe Robot Amfibi untuk Monitoring Limbah Cair pada Sungai Kawasan Industri," Institut Teknologi Sepuluh Nopember, 2017.

[8] S. N. RI, Undang-Undang Republik Indonesia nomor 34 Tahun 2004 tentang Tentara Nasional Indonesia. Indonesia, 2004.

[9] I. S. (Editor), "80 Persen Kekuatan Koopssus untuk Pengintaian: Pasukan Elite TNI untuk Lawan Terorisme," JawaPos.com. PT Jawa Pos Grup Multimedia, 2019. [Online]. Available: https://www.jawapos.com/nasional/hankam/31/ 07/2019/80-persen-kekuatan-koopssus-untukpengintaian/.

[10]G. Dasuqi, "Wiranto Apresiasi Kemampuan TNI Hancurkan Musuh dalam Latgab di Situbondo," detiknews, 2019. [Online]. Available: https://news.detik.com/berita-jawa-timur/d4704061/wiranto-apresiasi-kemampuan-tnihancurkan-musuh-dalam-latgab-di-situbondo.

[11]P. Scharre, Robotics on the Battlefield Part II: The Coming Swarm. Washington DC: Center for a New American Security., 2014.

[12] G. P. Cikarge and P. Utami, "Analisis dan Desain Media Pembelajaran Praktik Teknik Digital sesuai RPS," ELINVO(Electronics, Informatics, Vocat. Educ., vol. 3, no. 1, pp. 92-105, 2018.

[13]P. Utami, G. P. Cikarge, M. E. Ismail, and S. Hashim, "Teaching Aids in Digital Electronics Practice through Integrating 21st Century Learning Skills using a conceptual approach," in Journal of Physics: Conf. Series, 2018, pp. 1-9.

[14] J. L. Pita and F. O. Saavedra, "UAV Trajectory Management: Ardupilot Based Trajectory Management System," in Proceedings - MDPI, 2019, vol. 21, no. 8, pp. 1-2. 